\title{
Users and Contexts of Use of Romanian Multilingual Dictionaries
}

\author{
Mihaela Mocanu, Social Sciences and Humanities Research Department, \\ Institute for Interdisciplinary Research, Alexandru Ioan Cuza \\ University of Iași, Romania (mocanu.mihaela@uaic.ro) \\ and \\ Alina-Mihaela Bursuc, A. Philippide Institute of Romanian Philology, \\ Romanian Academy, Iași Branch, Romania \\ (alina.bursuc@hotmail.com)
}

\begin{abstract}
A significant number of multilingual dictionaries (in at least three languages) were published in Romania after the Revolution of December 1989. In the context of an unprecedented evolution of multilingualism, experts in various fields, as well as higher education professors identify specific communication needs and potential users and foresee preferential contexts of dictionary use. This article presents the outcomes of a study on the main categories of users and contexts of use of multilingual dictionaries edited in Romania after 1989. This analytical approach targets a representative sample of dictionaries selected on the basis of three criteria imposed by the research limits: temporal (dictionaries edited in the period 1990-2010), idiomatic (works presenting the list of entries in Romanian) and formal (the multilingual character stated explicitly in the title of the dictionary). The first part of the article accounts for the stage of research related to dictionary users and a short presentation of Romanian lexicography in general and of multilingual lexicography in particular. The second part of the study describes the methodology and proposes a systematization of the categories of potential users and the contexts of dictionary use as envisaged by the authors of the dictionaries under analysis.
\end{abstract}

Keywords: ROMANIAN LEXICOGRAPHY, MULTILINGUAL DICTIONARIES, USERS, CONTEXTS OF DICTIONARY USE, PRAGMATICS

Résumé: Utilisateurs et Contextes d'Emploi des Dictionnaires Multilingues

Roumains. En Roumanie, après la Révolution de décembre 1989, un nombre impressionnant de dictionnaires multilingues (dans au moins trois langues) fut publié. Dans les conditions de l'évolution sans précédent du multilinguisme, les spécialistes des différents domaines et les professeurs universitaires de langues étrangères captent des besoins de communication spécifiques, identifient des potentiels utilisateurs et préconisent des contextes préférés d'emploi des dictionnaires. Cet article présente les résultats d'une étude sur les principales catégories des utilisateurs et des contextes d'emploi des dictionnaires multilingues édités en Roumanie après 1989. La démarche analytique vise un échantillon représentatif de dictionnaires, choisi à partir de trois critères imposés par les limites de la recherche: le critère temporel (les dictionnaires édités dans la période 1990-2010), le critère idiomatique (les travaux qui présentent la liste des entrées en roumain) et le critère formel (le caractère multilingue clairement présenté dans le titre des dictionnaires). La première partie de l'article contient l'état de la recherche relatif aux utilisateurs des dictionnaires et une brève présen- 
tation de la lexicographie roumaine, en général, et de celle multilingue, en particulier. La deuxième partie de l'étude présente la méthodologie utilisée et propose une systématisation des catégories des utilisateurs potentiels et des contextes d'emploi préconisés par les auteurs des dictionnaires analysés.

Mots-clés: LEXICOGRAPHIE ROUMAINE, DICTIONNAIRES MULTILINGUES, UTILISATEURS, CONTEXTES D'EMPLOI, PRAGMATIQUE

\section{Introduction}

The main purpose of lexicography has always been to provide an inventory of and to explain the lexis of a language, be it a general lexis or a specialized one, for the speakers of that specific language or for the speakers of other languages. With the development of pragmatics, there occurs a shift of focus from the study of language in terms of the relationships between linguistic signs towards the relationships between verbal signs and their users. The development of pragmatics impacts on both linguistic studies, as the research on any type of text (dictionaries included) involves concepts specific to pragmatics, and the manner in which texts are elaborated. The authors and/or editors of dictionaries (regardless of them being lexicographers or not) place increased emphasis on the 'user's perspective' when elaborating dictionaries. In the texts that constitute the prefaces of dictionaries generally three main strategies that prove a transition of focus from the lexis to the users are employed: (i) the identification of the users' needs in relation to actual social realities (e.g. the emergence and development of new socio-professional categories) and the manner in which the content is organized depending on the aforementioned needs, marked by an ever increasing influence of the publishing houses upon the authors of dictionaries; (ii) the analysis of the profile and the assignment of the target readers/users; (iii) an invitation to the users to participate in the lexicographic approach (not only in view of the elaboration and publication of the dictionary, but also with regard to the impact and the improved quality of lexicographic products). Each of these strategies will be analyzed from the speech acts theory perspective (locutionary, illocutionary, perlocutionary), in order to emphasize the manner in which dictionary authors adapt to the users' needs and socio-cultural profiles.

Taking into account the fact that the value of a dictionary also resides in the manner in which it manages to relate the lexicographic data to the specific needs of the target audience, this paper proposes an analysis of Romanian multilingual dictionaries issued in Romania after the Revolution of 1989, from the perspective of the categories of users targeted by these dictionaries and the contexts of dictionary use anticipated by the authors of the respective dictionaries. The study is organized as follows: the first part includes a review of the meta-lexicographic research directions, with a special focus on user-oriented studies, as well as a review of the history of Romanian lexicography, whereas 
the second part presents the methodology and the outcomes of the analysis of multilingual dictionaries.

\section{State of research}

The elaboration of dictionaries is motivated by the identification of practical necessities among potential users, while the normative character and the authority of such works raise the issue of the responsibility of lexicographic approaches, since: the dictionary was a resource of what was considered to be the best or correct language (Hartmann and James 1998: VII). However, the authors of dictionaries started only in the 20th century to shift the focus of their interest towards a 'user-oriented perspective'. 'One of the principal advances in lexicography in recent years has been the focus on the user perspective, that is the realisation that different users have different reasons for using a dictionary, and that the dictionary can, and should, respond to these' (ibid. VIII).

The digitization of lexicography challenges authors to resort to a deep restructuring of the process involved in the elaboration of dictionaries. According to Sue Atkins, the real challenge is not 'how the computer can help us to produce old-style dictionaries better, but how it can help us to create something new' (Atkins 1996: 516). The storage and consulting of dictionaries by the users are also subject to important changes following the digitization of lexicography, which allows users to build up 'digital libraries' of resources. From this perspective 'the future dictionary is rather an integrated tool or a number of tools in a professional user's toolbox where it coexists with other language technology products such as encyclopaedic sources of reference, different types of corpora, corpus analysis tools [...], as well as corpus compilation software, translation memory systems, etc.' (Varantola 2002: 35).

The users themselves can become authors of dictionaries, leading to the rapid expansion of 'collaborative lexicography' where dictionary information is created end edited by users (Nesi 2016: 580).

Dictionary user research 'takes account of the profiles of dictionary users; the various contexts of dictionary use; the functions of the dictionary in its many situations of use; and the skills necessary for, and brought to bear on, dictionary use' (Hartmann and James 1998: VIII).

Two of the aspects analyzed in user-oriented studies relate to the issues the users have to cope with, and the systematization of user categories and contexts of use. Dictionary users face numerous challenges for which various solutions are proposed. On the one hand, there are authors who, despite targeting a larger audience, end up producing a dictionary destined to a specific segment of audience. In such cases, the following aspect needs to be considered: 'the dictionary maker naturally has to take into account all potential users and pay special attention to the largest groups of users and buyers' (Varantola 2002: 30-44). On the other hand, there are dictionaries with structures that render the task of consulting them rather difficult for the user, who fails to access and interpret 
the data that is provided (Pricop and Mocanu 2019: 130). The suggested solution is to provide 'a model of dictionary usage or a model for the decoding of lexicographic definitions' (Bidu-Vrănceanu 1993: 6). It is thus necessary to 'place more responsibility on the dictionary makers who, as professionals, should have a holistic view of what their dictionary offers to its users' (Kalliokuusi and Varantola 1998: 601-610).

Literature distinguishes between three main categories of users: language learners, non-professional users and professional users (Varantola 2002: 30-44). Another classification of users, this time only in relation to explanatory monolingual dictionaries, distinguishes between: '(i) readers referred to as 'cultivated', whose mother tongue is the described language; these readers are proficient users of the language; (ii) readers with imperfect skills in their mother tongue, whose aim is to enhance their competence and language skills and (iii) users of a pedagogical profile (the users are always teachers/pupils/students) who are only supposed to focus on the information that is pertinent for systematic learning from a determined perspective' (Bidu-Vrănceanu 1993: 6-7). Literature on the topic also emphasizes the variety of contexts of dictionary use: 'Dictionaries can thus be used in various ways in language teaching and language learning but also consulted as tools in "non-learning" activities, for example in reading comprehension, text production and in professional translation' (Varantola 1997: 30-31). According to the functional theory of lexicography, there are two categories of contexts of dictionary use: 'there are two main groups of use situations: cognition and communication-oriented situations' (León Araúz et al. 2008: 998).

\section{Multilingual Romanian lexicography}

In Romania, the production of multilingual dictionaries occurs in two significant stages: in the 17th-19th centuries dictionaries are produced to fulfill communication needs, while in the 20th-21st centuries multilingual terminological dictionaries are issued to serve professional needs. During the first stage, a traditional line becomes visible, which gradually fades by the end of the 19th century:

The real practical needs that have led to the emergence and development of national lexicography explain to a large extent the geographic distribution of the issued works, as well as their internal composition (first of all, the constituent languages) (Seche 1966: 181).

In the last decades of the 19th century, the Romanian traditional plurilingual lexicography was on the verge of irremediable decline, due to the obvious lack of practical usefulness of the works it had produced. As they cumulated several bilingual dictionaries and consequently became difficult to consult, polyglot dictionaries were eventually abandoned in favor of bilingual dictionaries proper (ibid. 1969: 317). 
Starting with the second half of the 20th century, the number of Romanian multilingual dictionaries 'increases constantly in order to meet professional needs' (ibid. 318).

The first known multilingual dictionary in Romania is a lexicon in Latin (the source language), Romanian and Hungarian (the target languages), dating from 1687-1701. Subsequently, in the second half of the 18th century, a series of multilingual lists of names of plants are issued (for the first one, dating from 1783, the source language is still Latin), along with manuscript vocabularies in which Romanian is placed in relation with Greek, French, German and Russian (languages whose culture influenced the Romanian culture at the time), as well as a series of multilingual dictionaries elaborated by the representatives of the Transylvanian School. The ever-increasing interest for the elaboration of a general dictionary of the Romanian language becomes, at the end of the 18th century, one of the main desiderates of the Transylvanian School. However, since the communication needs of the Transylvanian territory at the time, between different ethnic groups (Romanian, Hungarian, German) made it practically impossible to achieve such desiderate, multilingual dictionaries are produced instead. The first explanatory and etymological dictionary of the Romanian language ever printed is Lexiconul de la Buda [The Buda Lexicon], issued in 1825. However, the plant names glossaries remain dominant up to the end of the century, representing a constant feature of Romanian multilingual lexicography. In the 20th century, due to the progressive development of science and various technical fields, a significant number of multilingual terminological dictionaries are issued, especially by the Technical Publishing House. The best such dictionary from a lexicographic point of view was The Romanian Technical Lexicon, issued in the mid-20th century. At the beginning of the 21st century, of the terminological multilingual dictionaries we should mention at least almost 50 multilingual dictionaries of a normative character belonging to an academic series: Explanatory Dictionaries for Science and Technology and Explanatory Dictionaries for Exact Sciences.

We should also emphasize the fact that Romanian multilingual dictionaries have a perceived documentary value rather than a linguistic, scientific one. Some works stand out indeed (The Buda Lexicon, according to Mocanu 2019: 170), yet not due to their multilingual component, but rather due to their etymological and/or explanatory component, representing different stages or attempts aimed at the elaboration of The Romanian Language Dictionary. Although during the 20th century the Romanian lexicographic technique improves, multilingual terminologies are still not dealt with from a linguistic perspective, but rather as inventories and parallel term lists. Very few exceptions can be noted along with a few dictionaries aimed at the learning of foreign languages and which are treated somehow from a linguistic perspective, as they were elaborated by philologists specialized in foreign language teaching. The development of digital technologies led, in Romania as well, to the development of electronic multilingual dictionaries and terminological databases. Hence the 
decrease of the authors' and editors' interest in the elaboration and publication of terminological dictionaries, multilingual dictionaries included, a phenomenon that started around the year 2010.

\subsection{Multilingual dictionaries after the Revolution of December 1989}

For Central and Eastern European countries, the year 1989 was a year of crucial changes, the transition from various types of communism towards democracy occurring differently for each different country. The Revolution of 1989 triggered substantial political, social, economic, cultural, and scientific changes. From a social perspective, an increasing mobility of the population from Romania towards Western Europe and from Europe towards Romania can be observed from one year to another, generating linguistic contacts and a constant need for an accelerated acquisition of foreign languages. From an economic and cultural viewpoint, important changes can be noted with regard to the editorial market, influenced by the increasing number of private publishing houses. The products recording the biggest sales are now dictionaries, regardless of their type. Some of the publishing houses turn into private businesses, forming editorial groups with their own distribution services, while others stick to the structure of the National Culture Press and Publishing House and subsequently become self-financed public publishing houses, supported by the relevant ministries.

The universe of books is undergoing profound changes [...] in all its aspects, editorial life is complex and diverse, the book offer is adapted according to the readers' demands; however, based on governmental policies and subsidies, cultural programmes of a national interest that could not be supported without the state's intervention are also targeted (Buluță 1996: 77).

However, the private initiative dominates the Romanian editorial market, where the market economy laws and the Western editorial model are already in force. As far as the scientific field is concerned, information from various fields are absorbed rapidly and massively, contributing thus to the formation and development of various terminologies in the Romanian language.

With regard to dictionary editing, the first decade following the Revolution of 1989 is marked by a gap between the dynamics of lexicographic production (the number of lexicographic works increases significantly every year) and the absence of coherent editorial policies at a national level (according to Mocanu 2017). During the first decade (1990-1999) after the Revolution, 86 multilingual dictionaries are published in Romania, as compared to only 27 multilingual dictionaries in the previous decade. The quality of lexicographic editions is also subject to many changes: whereas before 1989 most dictionaries were edited under the patronage of state institutions (various Ministries, the Romanian Academy, higher education institutions, and the like), in the following years the editing of books is liberalized and the access to printing becomes 
readily available. This aspect is reflected in the heterogeneous character of Romanian lexicography after 1989: academic, professional editions co-exist with dictionaries drafted by specialists in various fields with no specialized lexicography training, an aspect which impacted on the quality of the lexicographic works issued during that period.

\section{Methodology}

\subsection{Object of study and sources}

The object of our study refers to the categories of users and the contexts of dictionary use considered by multilingual dictionary (with at least three component languages) authors who published their works in Romania after the sociopolitical events in 1989 known as 'the Revolution of December 1989'. The framework of our research requires the analysis of relevant data from a limited, but representative sample of multilingual dictionaries issued after 1990. The research aim refers, on the one hand, to the identification and systematization of the main categories of users and on the other hand, to the identification and (brief) description of contexts of dictionary use. According to the data provided by the first and only inventory of Romanian multilingual dictionaries (Pricop et al. 2017: 175-339), in the period 1990-2016, 303 such works were drafted and published, of which 86 titles were issued in the period 1990-1999, 202 titles in the following decade and 25 titles in the period 2011-2016. Taking into account the fact that for the decade that ended with the events in 1989, namely the period between 1980 and 1989, there are 27 titles (Pricop et al. 2017: 160-174), one can note a lexicographic 'boom' of a multilingual type in the period 1990-2010, with an obvious peak between 2001-2006 and a visible decline after the year 2010 (see Figure 1).

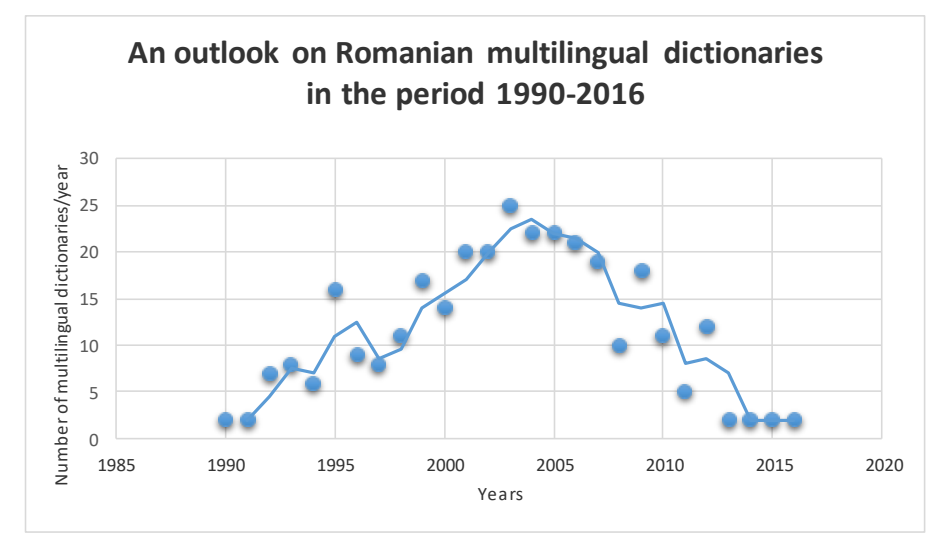

Figure 1: An outlook on Romanian multilingual dictionaries 
A pertinent explanation for the impressive number of dictionaries (no less than 288) issued during the most prolific decades for the Romanian multilingual lexicography (1990-2010), is to be offered by the outcomes of the analysis carried out in this study. The selection of a representative sample for the analysis is made according to two (meta)linguistic criteria: (1) Romanian as the source language, respectively (2) the multilingual character rendered explicitly in the titles of the dictionaries. The status of the Romanian language varies within multilingual dictionaries: in the vast majority of these works, Romanian is the source language, yet there are some dictionaries in which Romanian is one of the target languages - the main word list being rendered into a foreign language (this was mainly the case at the beginnings of Romanian multilingual lexicography, when the main language was either Latin or Hungarian, while in recent times this is the case of the dictionaries of informatics, where English is the source language). The selection of a dictionary word list consists in a complex, often original process in which the user's perspective is of utmost importance. Consequently, we have regarded the selection of the list of entries at the Romanian language level as a core criterion in the selection of dictionaries used in our analysis. With regard to the 288 dictionaries published between 1990 and 2010, we have noted that for 221 works the list of entries is drafted in Romanian, whereas for the remaining 67 titles, the source language is a foreign language (Latin, English, Russian, French or Greek), in a ratio of approximately 3:1.

The monolingual or bilingual character of a dictionary is almost never rendered explicitly in the title, since the language or languages used are usually specified (e.g. Romanian-French Dictionary). In the case of multilingual dictionaries, a brief analysis of the titles (Pricop et al. 2017: 9-30) reveals two modalities used for indicating the multilingual character: the use of an explicit determinant (multilingual, polyglot, plurilingual or trilingual) or the enumeration of the component languages (to which the determinant polyglot is sometimes added). These specifications with regard to the type of dictionary and its polyglot nature reflect the clear intention of the author and inform the user about the content of the work, thus facilitating the selection of a certain dictionary according to the user's needs. As far as the 288 dictionaries issued in the period 1990-2010 are concerned, 73 titles render the multilingual character in an explicit manner, while in the remaining 215 titles this is either implicit (the component languages are listed) or is not mentioned at all (the field is the only indicated element). Out of the 288 dictionaries issued in the period 1990-2010, just 36 multilingual dictionaries display the two selection markers concomitantly (Romanian as the source language and the polyglot nature rendered explicitly, see Figure 2). 


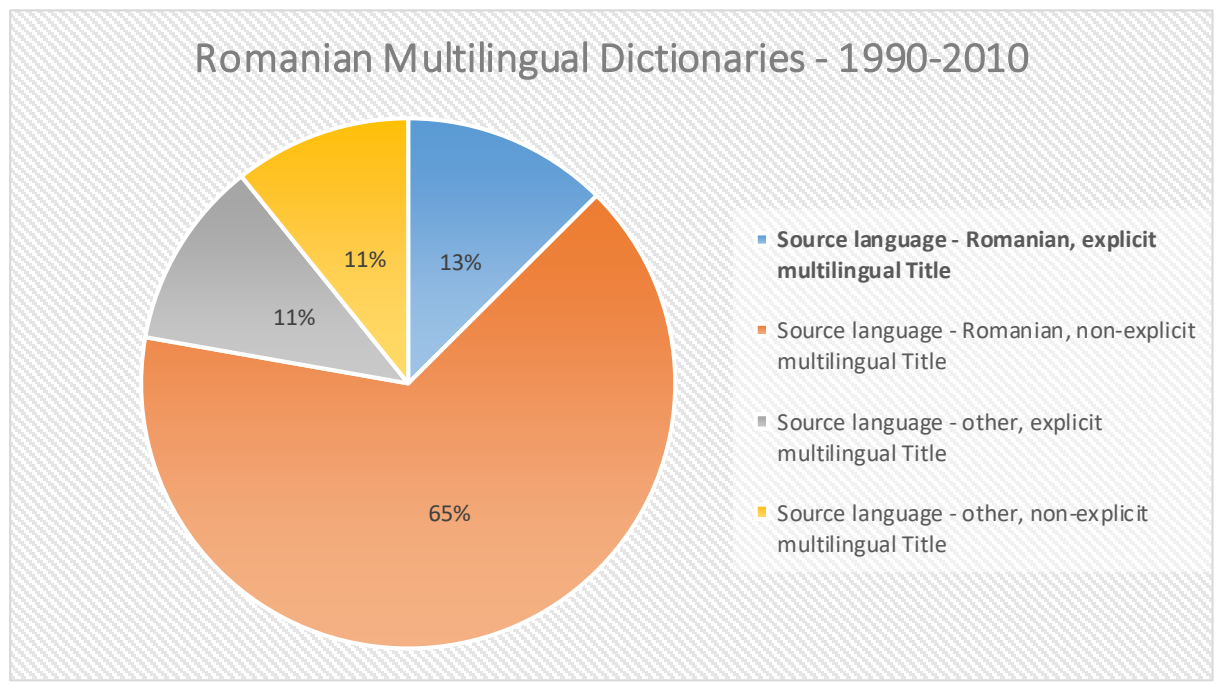

Figure 2: Romanian multilingual dictionaries between 1990-2010 (source language and title)

\subsection{Documentation and filing}

The multilingual dictionary, with its specific frame structure (body of the dictionary and indices) is usually preceded, in pragmatic terms, by a 'discourse of the emitter' made of various introductory texts (prefaces, indications for use, etc.) signed by the authors and/or the editors (according to Van Campenhoudt 1997). The introductory texts usually specify the target readers - the users, the actual argument of the elaboration - and their communication and/or professional needs, namely the contexts of usage, that usually represent the answers to the following questions: For whom?, Why?, To what purpose? In order to identify, systematize and describe the users and the contexts of dictionary use we have extracted from the introductory texts of the 36 selected dictionaries various types of information regarding: the way in which 'receivers are designated' (in pragmatic terms), users and contexts of dictionary use, editorial needs and offer, 'requests for answers', acknowledgements addressed to collaborators in different stages, clarifications regarding previous works or editions. The basis of our analysis consists mainly of a corpus of introductory paragraphs and fragments that concentrate information regarding users and contexts.

\subsection{Analysis and results}

The analysis of the data provided by authors and/or editors is conducted in 
several stages: the identification of the categories of users and contexts of dictionary use, the extraction of systematization criteria, the classification of categories according to the extracted criteria, and the setting of (proto)types. In pragmatic terms, dictionary authors and editors can be assimilated to the sender, while the users can be assimilated to the receiver. The analysis of the 'sender's discourse', rendered in the introductory texts (prefaces, forewords, instructions for use and the like) of multilingual dictionaries identifies elements that are similar to the three components of speech acts: locutionary, illocutionary and perlocutionary (according to Ionescu-Ruxăndoiu 2003: 22-23). The locutionary dimension of the discourse involves, also in the case of dictionaries, two basic operations: 'the designation of the receiver' and the 'request for an answer'. The designation of the receiver, identified in most of the works we analyzed, is achieved by means of various formulae that contain intentions, representative for the 'illocutionary' dimension (offers, promises, recommendations). Thus, such a work 'addresses' (Biriș 2000, Iliescu et al. 2001, Frâncu 2002, Frâncu et al. 2003, Vlad et al. 2004, Surdu and Surdu Soreanu 2009), 'is destined to' (Dinu 2000, Tetean and Vinţeler 2002, Becea 2003, Hanga et al. 2008) or 'is made available for' (Ioniță and Marin 2002) a certain user. The dictionary 'is a useful and very important instrument for' (Țarcă 2009), 'can be extremely helpful for' (Becea 2003), 'can be used by' (Frâncu et al. 2003, Șelaru et al. 2004), 'aims at offering assistance to' (Frâncu et al. 2003), 'answers the needs of' (Dincă et al. 2004), 'aims at assisting' (Grozavu and Kocsis 2005). The authors formulate claims such as: 'we recommend' (Plahteanu 2005) or 'we hope it to be useful especially to' (Corniță, 2007). The introductory texts of a few analyzed works do not contain any such formulae (Butnaru et al. 2002, Dvoracek 2002, Manoliu et al. 2002, Cosma and Cosma 2005, Lungu et al. 2006, Lupchian and Lazăr 2010). Our analysis indicated the existence of two categories of multilingual dictionaries: dictionaries in which the target users are explicitly designated in various introductory sections and dictionaries in which the target users are not designated. In most introductory sections, the receiver is required to accept an active part, contributing with improvement suggestions for prospective future editions (Firuță and Popa 1992, Sopa 1993, Chira and Iliescu 1995, Chira 1999). In the prefaces of their works, the authors of future editions thank all those who offered suggestions for improvement, a clear expression of the performance of a perlocutionary act, when the effect coincides with the authors' intention. Moreover, the authors of most dictionaries we analyzed also address the people who already contributed, in one way or another (translation, revision, editing, printing, etc.) to the issue of the respective work.

The categories of users regarded as target audiences by the authors of the dictionaries we analyzed can be systematized based on four criteria: the numerical criterion (one/several categories aimed at by a dictionary), the lexicological criterion (the nature of the lexis recorded in the dictionary), the professional criterion (the measure in which users are conditioned by their professional background) and the idiomatic criterion (the degree of proficiency in the 
component languages). The main contexts of dictionary use anticipated by dictionary authors can be systematized as such: the translation of specialized texts, research using foreign specialized literature, learning a foreign language, communication in certain situations, and recording and listing of Romanian terminology in a specific field (the main lexicological and lexicographic approach). The results of the analysis: the systematization of the categories of users and the description of the main contexts of dictionary use, rendered in two distinct chapters, with a specific emphasis on the results that are relevant for most dictionaries.

\section{Categories of users}

The Romanian literature in the field does not include any studies on the users of multilingual dictionaries or any classification of these users, except for a typology of monolingual dictionary users (Bidu-Vrănceanu 1993: 6-7).

\subsection{The numerical criterion}

Our analysis has revealed that whereas the authors of a few dictionaries are restrained to a single category of users, most authors designate several categories of users, while some others choose not to mention any category of users whatsoever (Butnaru et al. 2002, Manoliu et al. 2002, Lupchian and Lazăr 2010). Thus, the authors of a few dictionaries state that they consider a single category of users: students (Nagy 1991), professionals working in a certain field (Chira and Iliescu 1995, Savin 1997), specialists in a certain field (Mihalciuc et al. 1995) or tourists (Firuță and Popa 1992). Most dictionaries target at least two categories of users: specialists and translators (Dinu 2000, Vlad et al. 2004); specialists and students (Hanga et al. 2008); specialists and people with an interest in the field (Frâncu 2002, Surdu and Surdu Soreanu 2009); students and people with an interest in the field (Mănăilă et al. 1995); specialists and people interested in related fields (Şelaru et al. 2004: 3); specialists and professionals in a certain field, students (Biriș 2003); specialists, students and translators (Plahteanu 2005); specialists, students, translators, and foreign languages learners (Frâncu et al. 2003); specialists, university professors, students and people with an interest in the field (Dincă et al. 2004); specialists, university professors, students and decision-makers (Grozavu and Kocsis 2005). According to the systematization based on the numerical criterion, the dominant type of multilingual dictionary is the one targeting several categories of users.

\subsection{The lexicological criterion}

A smaller number of multilingual dictionaries record either the basic vocabulary of the Romanian language (Iliescu et al. 2001), or a nucleus of the basic vocabu- 
laries belonging to several languages (Firuță and Popa 1992, Cuza 1994, Tetean and Vinţeler 2002, Corniță 2007). The targeted users are foreign language learners: either foreigners who learn Romanian or Romanians who learn a foreign language. The users can be professionally determined (pupils, students, teachers) or not.

Most of the dictionaries we analyzed list terminologies of some specific fields. Being tools that aim at facilitating the access of the audience to the corresponding terms in a foreign language, most multilingual dictionaries we analyzed target, first and foremost, the specialists, indicating the respective fields: medical sciences (Nagy 1991), car engineering (Sopa 1993), Physics and Mathematics (Mănăilă et al. 1995), Economy (Mihalciuc et al. 1995, Frâncu et al. 2003), wood industry (Stoian 1995), hydrology, water management, meteorology, the protection of the environment (Savin 1997), agricultural technique and food industry (Biriș 2000), zootechnics (Dinu 2000), skiing (Becea 2003), forestry (Dincă et al. 2004), hunting (Șelaru et al. 2004), ethology and animal physiology (Vlad et al. 2004), the environment and environmental sciences (Grozavu and Kocsis 2005), machine construction (Plahteanu 2005), poultry industry and the industry of poultry-based products (Surdu and Surdu Soreanu 2009). Some of the works indicate the profession as such: the staff of the Ministry of Domestic Affairs (Ioniță and Marin 2002), musicians (Cosma and Cosma 2005), veterinarians (Lungu et al. 2006), legal experts (Hanga et al. 2008). According to the systematization based on the lexicological criterion, the dominant type of multilingual dictionary is the dictionary addressed to specialists in specific fields.

\subsection{Degree of professional determination}

The category of professionally determined users (see supra 5.2.) is targeted by terminological dictionaries and falls into two sub-categories: users involved in the educational system (pupils, students, teaching staff) and users who have various degrees of specialization in a certain field, with the specification of the specializations and/or fields of activity. Student users fall, in turn, into two sub-categories: students from a certain specialization, who acquire specialized multilingual terminology and students who, regardless of their specialization, are interested in enhancing their idiomatic skills in various foreign languages. The mainly didactic purpose of multilingual dictionaries is emphasized by the authors in the prefaces to their works. Thus, some dictionaries are conceived as auxiliaries for certain courses, guidelines for practical works, manuals or other didactic/teaching materials (Nagy 1991). We should note that the term 'specialist' is used both with a broader meaning and a specific one, as the authors state that in their view the specialists are people who work in research, people who work in research, planning, development, production, sales or people who work in research, translation, interpreting and education. Another professional category is represented by translators who mainly have a philological formation and training and who translate and interpret texts to and from foreign lan- 
guages (Mănăilă et al. 1995, Mihalciuc et al. 1995, Stoian 1995). Besides the categories determined according to their educational or professional background, there are also undetermined categories of users who have particular interests: people who are interested in a specific field or people who are interested in a related field (Frâncu 2002, Dincă et al. 2004, Șelaru et al. 2004), people who want to carry out a conversation on topics related to a specific field (Constantinescu et al. 2003), people who are interested in learning foreign languages (Constantinescu et al. 2003), self-taught people (Manual 1992). According to the systematization based on the degree of professional determination, the dominant type of multilingual dictionary is the one addressed to those users whose level of studies and professional status are determined.

\subsection{The language proficiency in the component languages}

In principle, the multilingual dictionaries elaborated in Romania mainly target people who know the language, the Romanians, as (native) speakers of Romanian (regardless of their professional determination) (Mihalciuc et al. 1995). The Romanian audience is considered from a geo-political or touristic perspective: (future) members of the European community (Dvoracek 2002, Țarcă 2009), tourists (Firuță and Popa 1992, Stănciulescu et al. 1998) or as communicators, a recent profession listed in the official classification of professions (Corniță 2007). There are also the users who are familiar with one or several target languages, the foreigners who do not speak Romanian, but intend to learn it while learning a particular terminology (Nagy 1991). A small number of dictionaries target both Romanian and foreign users with regard to elementary skills (beginner level) in either a foreign language or Romanian (Firuță and Popa 1992, Iliescu et al. 2001, Tetean and Vinţeler 2002). The authors of some other dictionaries address explicitly the translators who interpret and translate texts, and native users of Romanian who can speak at least two of the component languages (the source language and a target language) of the respective works (Frâncu et al. 2003, Vlad et al. 2004). According to the systematization based on the criterion regarding the language proficiency in the component languages, the dominant type of multilingual dictionary is addressed to the users who are familiar at least with the source language, Romanian in this specific case.

\section{Contexts of multilingual dictionaries use}

The Romanian literature in the field does not include any studies on multilingual dictionaries use or any attempt at systematizing these dictionaries.

\subsection{The translation of specialized texts}

One of the main categories of users targeted by multilingual dictionaries is rep- 
resented by translators. The use of multilingual dictionaries is mandatory for the accurate translation of the technical and scientific documentation accompanying machinery and installations in agriculture and the food industry (Biriș 2000: 3), economic texts (Frâncu et al. 2003), terms belonging to biotechnology (Manoliu et al. 2007: 3) or the Romanian legal terminology in the European context (Hanga et al. 2008).

\subsection{Documenting based on foreign literature and the proper understand- ing of multilingual terminology}

The monolingual explicative dictionary is necessary in the development stage of a terminology, according to the authors of a zootechnics dictionary (Dinu 2000: 6). Considering the tendency of 'internationalization' of the terminologies, a stage where there might occur confusions or inappropriate uses of zootechnical notions (ibid.), animal ethology and physiology notions (Vlad et al. 2004: 5) or musical notions (Cosma and Cosma 2005: 5), making use of multilingual dictionaries becomes a necessity. The use of a multilingual dictionary is necessary to access and use foreign literature, in order to train specialists from particular fields (medical biophysics - Nagy 1991, skiing — Becea 2003, forestry Stoian 1995, Dincă et al. 2004). The development of a multilingual dictionary in an international project, with native editors of several European languages, aims at:

... introducing a common language that will facilitate the educational process, the research activity, and the legislation, etc. in the environmental field, contributing to supporting the policies and initiatives of the EU Member States and the candidate countries (Grozavu and Kocsis 2005: 6).

In a multilingual illustrated dictionary, the illustrations are not only explanatory (the image renders the proper meaning of a term), but rather play the part of a 'universal intermediary between different languages' (Plahteanu 2005: 3), contributing to the dissemination and wider use of information and multilingual terminology in the field. The selection of terms in a dictionary of aviculture and poultry product industry is dictated by practical needs: 'to help identify quickly and precisely the terms used in specialized periodicals and books published in the three important foreign languages' (Surdu and Surdu Soreanu 2009: ix).

\subsection{Acquiring a foreign language}

Acquiring a foreign language represents a didactic goal that can be achieved by including multilingual dictionaries in the learning process (with bilingual ones regarded as more appropriate). Two types of dictionaries are noted in the analyzed corpus sample: those that contain the basic vocabulary of some languages and are addressed directly to the Romanian (or foreign) learners of foreign lan- 
guages, respectively a series of terminology dictionaries, aimed at foreign language learners, although their main category of users is represented by specialists in the field. The multilingual dictionary for foreign language learning may contain the basic vocabulary of the Romanian language being primarily dedicated to foreigners who learn Romanian (and secondly to Romanians who are thus provided in a single volume the translation of the basic vocabulary into a foreign language, Iliescu et al. 2001), or it may contain a balanced and representative basic fund for both Romanian and foreign languages, addressing a broad category of users (determined according to their educational or professional background: Romanian language learners and students who learn foreign languages according to the Romanian curriculum, teachers teaching either foreign languages or Romanian as a foreign language at all levels, Tetean and Vinţeler 2002, or indefinite: Romanian tourists, Firuță and Popa 1992).

\subsection{Acquiring multilingual terminology in a specific field}

A multilingual dictionary of medical biophysics terms is intended for limited use: namely the students from the biophysical specialization of the University of Medicine and Pharmacy of Timișoara (Nagy 1991). Another dictionary of pathological anatomy is conceived as an individual learning instrument for students at the Faculty of Veterinary Medicine to 'rapidly acquire an adequate medical vocabulary' that is at the same time multilingual (Lungu et al. 2006). The use of a dictionary of legal terms is necessary for the students of the Faculty of Law to acquire specialized terms in other languages (Hanga et al. 2008).

\subsection{The development of communicative skills}

Generally, dictionaries are tools that support communication between speakers of different languages; in some cases, this is the main objective of a dictionary. Certain multilingual dictionaries, though apparently terminological, compile inventories of a varied lexis encompassing both common terms specific to a certain field or to related fields and words used in ordinary conversational exchanges. Such dictionaries explicitly support the communication purpose, the dialogue between specialists or between specialists and the general public, on topics related to a specialized field. This is the case of a professional lexis addressed to the staff of the Ministry of Domestic Affairs, meant to support the dialogue with the general public or colleagues from similar structures belonging to the European and North American countries (Ioniță and Marin 2002: 2). It is also the purpose of a medical dictionary that 'responds to the needs of an immediate medical conversation', a useful tool 'not only for medical specialists, but also for anyone who wants to discuss medical matters in French or in English' (Constantinescu et al. 2003: 5). 
Other such communicative situations are: exchange of information between the participants to road traffic, during motor shows and auto fairs, respectively dialogues involving tourists or Romanian specialists engaged in international relations (Sopa 1993: 5; Firuță and Popa 1992: 5; Chira and Iliescu 1995: 7; Mihalciuc et al. 1995: 5; Selaru et al. 2004: 3; Cosma and Cosma 2005: 5). A special dictionary is the one dedicated to people working in different institutions (educational institutions included) and who are permanently or occasionally invested with the role of communicators (Corniță 2007: 15).

\subsection{The 'thesaurization' of Romanian terminology}

This aspect refers to a series of dictionaries with a secondary multilingual character, which focus on the delimitation and explicitation of the Romanian terminology in the field. In this respect, a dictionary of genetics is meant to provide its users with explanation for specific terms, so that these terms can be used with their real meaning, the definitions of the entries (some concise, others detailed) being rendered exclusively in Romanian (Butnaru et al. 2002). In this case, the dictionary is subject to 'a different type of integration in communication, as terms are provided synonyms in the main languages used at the international level' (Butnaru et al. 2002: i). The use of a library science-related thesaurus responds to the needs of indexing and retrieving the information contained in the documents belonging to Romanian small and medium libraries with encyclopaedic funds. In this particular case:

... the presence of terms in the other two participating languages, namely English and French, adds value to the instrument and widens the scope of its use (Frâncu 2002: i).

One must add that other dictionaries, while emphasizing the multilingual terminology they contain, equally preserve and store the Romanian terminology in the field (the Romanian lexical inventory of some previous editions: economic, tourism or foreign trade terminology - Frâncu et al. 2003, skiing terminology - Becea 2003, forestry terminology — Dincă et al. 2004).

\section{Conclusive remarks}

The purpose of practical lexicography consists in the recording and explicitation of various types of lexis for various users, yet the user's perspective becomes the focus of dictionary authors' interest only starting with the 20th century. User-oriented studies propose various classifications of the categories of users and contexts of dictionary use. Romanian lexicography has a history that spans over five centuries, being dominated by bilingual and multilingual dictionaries; we should mention that Romanian monolingual lexicography, on the other hand, is only one century and a half old. This study represents the 
first analytical approach based on information selected from the introductory texts of a representative sample of 36 multilingual dictionaries. The outcomes of the study are presented in two distinct chapters that deal with the systematization of the categories of users and the description of contexts of dictionaries use. Our analysis has indicated that the dominant type of multilingual dictionary targets several categories of users, determined from a professional viewpoint, proficient in Romanian and interested, due to their professions, in multilingual terminologies. The dictionaries that made the subject of our analysis are elaborated in order to serve various contexts: the accurate translation of foreign terminologies and of specialized texts, the acquisition and accurate use of a certain terminology, research using foreign specialized literature, learning a foreign language, the elaboration of dictionaries of specialized terms. Most dictionaries aim at facilitating communication, between Romanian and foreign specialists in various communication situations (information exchange, common interests, business partnerships, and others). This study emphasizes the huge need for rapid knowledge of foreign languages (as many as possible) that serve an immediate professional interest which the authors of multilingual dictionaries (including the ones we analyzed) were able to identify. The dictionaries we included in our sample represent the lexicographic expression of the social phenomenon triggered by the Revolution of December 1989 in Romania, which led to the opening of the country's borders towards Europe. This study represents a contribution to the field of Romanian metalexicography. The originality of the analytical approach derives from: (1) the nature of the corpus we analyzed (multilingual dictionaries issued in the first two decades after the Revolution of 1989) and (2) the pragmatic approach perspective, focused on categories of users and contexts of dictionary use. The analysis of the lexicographic corpus has emphasized, on the one hand, the authors' interest in the profile and more and more diverse needs of the categories of users and on the other hand, the need to adjust the lexicographic approach according to the specificity and particularities of the target audience, in order to produce high-quality lexicographic works.

\section{References}

\section{Dictionaries}

Becea, L. 2003. Dicţionar poliglot de schi. București: Editura Printech.

Biriș, S.-Ș. 2000. Dicţionar tehnic poliglot de mașini și instalaţii pentru agricultură și industrie alimentară: român, englez, francez, german, maghiar. București: Editura Printech.

Butnaru, G., M. Bodogai, A. Baciu and R. Zehan. 2002. Dicţionar de genetică poliglot. Timișoara: Editura Mirton.

Chira, V. 1999. Dicţionar poliglot explicativ de cardiologie. Cluj-Napoca: Editura medicală universitară 'Iuliu Haţieganu'.

Chira, C. and M. Iliescu. 1995. Dicţionar tehnic rutier poliglot. Cluj-Napoca: Editura Albastră. 
Constantinescu, I., G. Godeanu and M. Botorog. 2003. Dicţionar medical poliglot: român-francezenglez. București: Editura Garamond.

Corniță, G. (Coord.). 2007. Mimica. Dicționar multilingv (român, francez, englez, german, maghiar) / Mimicry. Multilingual Dictionary (Romanian, French, English, German, Hungarian). Baia Mare: Editura Universității de Nord.

Cosma, M. and R. Cosma. 2005. Dicționar multilingv de termeni muzicali. București: Editura Universității Naționale de Muzică.

Cuza, V. 1994. Dicţionar poliglot (engleză, franceză, germană, italiană,spaniolă, română). București: Editura Gramar.

Dincă, L., D. Drăghiciu and D. Chira. 2004. Dicţionar forestier poliglot. Român-englez-francez-german. Englez-Român. Francez-Român. German-Român. Brașov: Editura Silvodel.

Dinu, I. (Coord.). 2000. Dicţionar poliglot de zootehnie: română, franceză, engleză, germană, spaniolă. București: Editura Coral Sanivet.

Dvoracek, A. 2002. Europa în cuvinte-cheie: dictionar explicativ multilingv, român, francez, italian, spaniol. Vol. I (A-C). Iași: Editura Vasiliana'98.

Firuță, C. and A. Popa (Eds.). 1992. Dicţionar euro-turistic poliglot retroversiv. București: Editura Alcor S.R.L, Editura Arta Grafică.

Frâncu, N. (Coord.), S. Drăghici, A. Hârlăoanu and L. Șoptereanu. 2003. Dicţionar poliglot economic, de comerț exterior și turism: română, franceză, engleză, germană, spaniolă, rusă. București: Editura Garamond.

Grozavu, A. and L.Ș. Kocsis (Coord.). 2005. Dicţionar poliglot multimedia de mediu și de știinţe ale pământului. Iași: Editura Azimuth.

Hanga, V., R. Hanga-Calciu and I. Trifa. 2008. Dicţionar juridic polyglot. Român-englez-francezgerman-italian. Cluj-Napoca: Editura Cordial LEX.

Iliescu, M., C. Nedelcu, G. Scurtu, V. Neagu and A. Costăchescu. 2001. Dicţionar poliglot. Română. Engleză. Franceză. Germană. Italiană. Spaniolă. București: Teora.

Ioniță, T. and R. Marin. 2002. Lexic profesional poliglot: română, franceză, germană, engleză, spaniolă, italiană. București: Editura Ministerului de Interne.

Lungu, A., M. Parodi, V. Grieco and G.L. Fiore. 2006. Dicţionar explicativ poliglot de anatomie patologică veterinară. București: Editura Printech.

Lupchian, G. and C.A. Lazăr. 2010. Finanţe, bănci și contabilitate. Mic dicţionar poliglot. București: Pro Universitaria.

Mănăilă, D., C. Popa, D. Popa, I.M. Popescu and V.I. Vlad. 1995. Mic dicţionar poliglot de fizică, tehnică, matematică, în limbile română, engleză, germană, franceză. București: Editura Agora.

Manoliu, A., L.A. Oprică and S. Diaconeasa. 2002. Dictionar poliglot de biotehnologie: român-englezrus-francez. Iași: Editura Corson.

Manoliu, A., M.E. Sidoroff, L. Oprică, S. Diaconeasa and T. Tofan-Burac. 2007. Dicţionar poliglot de biotehnologie: român, englez, rus, francez, finlandez. Second Edition. București: Editura Tehnică.

Manual. 1992. Manual — dicţionar poliglot în 8 limbi: română, esperanto, franceză, engleză, germană, olandeză, spaniolă, italiană. Cluj-Napoca: S.C. Diamant de Arieș.

Mihalciuc, M., L. Mureșan, G. Stănciulescu and S.V. Stan. 1995. Dicţionar poliglot explicativ. Termeni uzuali în economia de piaţă. București: Editura Enciclopedică.

Mihalciuc, M., L. Mureșan, G. Stănciulescu, S.V. Stan and L.E. Csaba. 1996. Dicţionar poliglot explicativ. 1000 termeni uzuali în economia de piaţă. București: Editura Enciclopedică. 
Nagy, I.I. (Coord.). 1991. Dicţionar poliglot cu termeni de biofizică medicală. Timișoara: Editura LITO I.M.T.

Plahteanu, B. (Coord.). 2005. Dicţionar ilustrat poliglot în construcţia de mașini. Iași: Editura Performantica.

Savin, C. 1997. Dicţionar știinţific poliglot pentru domeniile: hidrologie, gospodărirea apelor, meteorologie, protecţia mediului și alţi termeni necesari din discipline conexe-complementare. Engleză, franceză, germană, spaniolă, rusă. (2 volumes 1996, 1997). București: Editura Tipored.

Șelaru, N. (Coord.), M. Georgescu, I. Svoronos, B. Ioriatti and P. Moise. 2004. Diç̧ionar poliglot de vânătoare. București: Editura Cynegis.

Sopa, S. 1993. Dicţionar tehnic poliglot. Motoare, automobile, tractoare. Română. Maghiară. Engleză. Germană. Franceză. Spaniolă. Cluj-Napoca: Editura Microinformatica.

Stănciulescu, G., N. Lupu and G. Țigu. 1998. Dicţionar poliglot explicativ de termeni utilizaţi în turism. București: All Educational.

Stoian, O. (Coord.). 1995. Dicţionar forestier poliglot: român, englez, german, francez în domeniile: silvicultură, exploatarea pădurilor, prelucrarea lemnului. (2 volumes). București: S.C. Forest Infodoc S.A.

Surdu, A.A. and R.V. Surdu Soreanu. 2009. Dicţionar poliglot de avicultură și industria produselor avicole. București: Editura Academiei Române.

Tetean, D. and O. Vinţeler. 2002. Dicţionar tematic poliglot: română, franceză, spaniolă, engleză, germană, rusă. Cluj-Napoca: Risoprint.

Vlad, I., V. Băcilă and I. Oprea. 2004. Dicţionar poliglot de etologie și fiziologie animală. Sibiu: Editura Universităţii Lucian Blaga din Sibiu.

\section{Other literature}

Atkins, B.T.S. 1996. Bilingual Dictionaries. Past, Present and Future. Gellerstam, M., J. Järborg, S.-G. Malmgren, K. Norén, L. Rogström and C. Röjder Papmehl (Eds.). 1996. Euralex '96 Proceedings I-II, Papers Submitted to the Seventh EURALEX International Congress on Lexicography in Göteborg, Sweden: 515-546. Göteborg: Göteborg University.

Bidu-Vrănceanu, A. 1993. Lectura dicționarelor. București: Editura și Atelierele Tipografice Metropol.

Buluță, G. 1996. Scurtă istorie a editurii românești. București: Editura Enciclopedică.

Hartmann, R.R.K. and G. James. 1998. Dictionary of Lexicography. London/New York: Routledge.

Ionescu-Ruxăndoiu, L. 2003. Limbaj și comunicare. Elemente de pragmatic lingvistică. București: Editura All.

Kalliokuusi, V. and K. Varantola. 1998. From General Dictionaries to Terminological Glossaries. Fontenelle, T., P. Hiligsmann, A. Michiels, A. Moulin and S. Theissen (Eds.). 1998. Actes EURALEX '98 Proceedings. Papers submitted to the Eighth EURALEX International Congress on Lexicography in Liège, Belgium: 601-610. Liège: English and Dutch Departments, University of Liège.

León Araúz, P., P. Faber Benìtez and C. Pérez Hernández. 2008. LSP Dictionaries and their Genuine Purpose: A Frame-based Example from MARCOCOSTA. Bernal, E. and J. DeCesaris (Eds). 2008. Proceedings of the XIII EURALEX International Congress, Barcelona, 15-19 July 2008: 997-1006. Barcelona: Institut Universitari de Lingüística Aplicada, Universitat Pompeu Fabra.

Mocanu, M. 2017. Dicționarele multilingve românești. O analiză comparativă. Studii de Știință și Cultură 13(3): 51-60. 
Mocanu, M. 2019. The Dictionary as Signifying Practice. A Semiotic Approach of the Buda Lexicon. Hermeneia. Journal of Hermeneutics, Art Theory and Criticism 22: 157-171.

Nesi, H. 2016. The Demands of Users and the Publishing World: Printed or Online, Free or Paid for? Durkin, P. (Ed.). 2016. The Oxford Handbook of Lexicography: 579-589. Oxford: Oxford University Press.

Pricop, A. (Coord.), A.-G. Marcu, M. Mocanu and O. Zamfirescu. 2017. Lexicografia poliglotă $\hat{\imath}$ secolele al XVII-lea-al XXI-lea: liste, vocabulare, glosare, dicționare, lexicoane, tezaure care conțin limba română. Bibliografie. Iași: Editura Universității 'Alexandru Ioan Cuza' din Iași.

Pricop, Alina-Mihaela and Mihaela Mocanu. 2019. The Design of Multilingual Dictionaries According to Users' Needs. Philologica Jassyensia 15: 119-135.

Seche, M. 1966-1969. Schiță de istorie a lexicografiei române [Brief History of the Romanian Lexicography]. (2 volumes). București: Editura Științifică.

Van Campenhoudt, M. 1997. Évaluation des terminographies multilingues: le dictionnaire nautique du capitaine Paasch face au dictionnaire aéronautique de l'ingénieur Schlomann. Hermans, A. (Ed.). 1997. Les dictionnaires spécialisés et l'analyse de la valeur, actes du colloque organisé en avril 1995 par le Centre de terminologie de Bruxelles (Institut libre Marie Haps): 75-115. Louvain-la-Neuve: Peeters.

Varantola, K. 1997. On the Information Needs of Dictionary Users. Karpova, O. (Ed.). 1997. Aktual'nye problemy teoretiaeskoj prikladnoj leksikografii: 98-110. Ivanovo: Ivan.

Varantola, K. 2002. Use and Usability of Dictionaries: Common Sense and Context Sensibility? Corréard, M.-H. (Ed.). 2002. Lexicography and Natural Language Processing. A Festschrift in Honour of B.T.S. Atkins: 30-44. Grenoble: EURALEX. 